\title{
PROX1 wt Allele
}

National Cancer Institute

\section{Source}

National Cancer Institute. PROX1 wt Allele. NCI Thesaurus. Code C74438.

Human PROX1 wild-type allele is located within 1q32.2-q32.3 and is approximately $53 \mathrm{~kb}$ in length. This allele, which encodes homeobox prospero-like protein PROX1, may play a role in both regulation of gene expression and neuronal development. Aberrant expression may play a role in tumor initiation. 